\title{
Induction of Epithelial Ovarian Cancer by Implantation of 7,12-dimethylbenz(a)athracene (DMBA) Coated Silk in Rats.
}

\author{
Ni Made Dwi Sandhiutami ${ }^{1,2}$, Wawaimuli Arozal ${ }^{3 *}$, Melva Louisa ${ }^{3}$, Deni Rahmat ${ }^{2}$, Puspita Eka Wuyung ${ }^{4}$, Mokhamad Fakhrul Ulum $^{5}$ \\ ${ }^{1}$ Doctoral Program in Biomedical Sciences, Faculty of Medicine, Universitas Indonesia, Jakarta, INDONESIA. \\ 2Faculty of Pharmacy, University of Pancasila, Jakarta, INDONESIA. \\ ${ }^{3}$ Department of Pharmacology and Therapeutics, Faculty of Medicine, Universitas Indonesia, Jakarta, INDONESIA. \\ ${ }^{4}$ Departement of Anatomical Pathology, Faculty of Medicine, Universitas Indonesia, Jakarta, INDONESIA. \\ ${ }^{5}$ Department of Clinic, Reproduction and Pathology, Faculty of Veterinary Medicine, Bogor Agricultural University, INDONESIA.
}

\begin{abstract}
Objective: This research aims to get the relevant animal model for epithelial ovarian cancer and ultrasonography approach to detect volume and size of ovarian cancer. Methods: Induction of ovarian cancer in rats was carried out using 7,12-Dimethylbenz [a] anthracene (DMBA) coated on silk suture and then implanted in the left ovary of female Wistar rats. Nodule were determined weekly after the first surgery by palpating the abdominal wall of rats. Utrasonography was carried out at $20^{\text {th }}$ week. Rats were euthanized, ovarian organs were taken and histopathological examination was performed with haematoxylin and eosin staining. Results: Nodules in DMBA-treated rats were noted at $16^{\text {th }}$ weeks post implantation and reaching a cummulative incidence of $96,4 \%$ at $24^{\text {th }}$ weeks. On ultrasound examination at the $20^{\text {th }}$ week, there were significant differences in left and right ovarian size and volume. The histological type of induced tumor included: serous carcinoma cell, clear cell carcinoma, sarcoma and squamous
\end{abstract}

carcinoma. Conclusion: The implanted 7,12-Dimethylbenz[a]anthracene (DMBA) coated silk suture in the ovaries rats can be used as animal model for testing therapeutics agent of ephitelial ovarian cancer and ultrasonography can determine the size and volume of tumors formed in ovary.

Key words: 7,12-Dimethylbenz[a]anthracene, Animal model, Epithelial ovarian cancer, Ultrasonography.

\section{Correspondence}

Wawaimuli Arozal, Department of Pharmacology and Therapeutics, Faculty of Medicine, Universitas Indonesia, Jakarta, INDONESIA.

Phone: +6281808408680

Email: wawaimuli@gmail.com

DOI: 10.5530/jyp.2019.11.12

\section{INTRODUCTION}

Ovarian cancer is a gynecological cancer that causes a leading mortality in women. The GLOBOCAN (IARC) data showed 239.000 women diagnosed with ovarian cancer in 2012. In the United States, 22.280 women were diagnosed with ovarian cancer in 2016 and 14.240 out from this number were died of cancer. In Indonesia, ovarian tumors are the third most common tumor in women based on the report of Badan Registrasi Kanker Perhimpunan Dokter Spesialis Patologi Indonesia in 2012 with a total of 1.195 cases. While the 2015, INASGO data showed 442 new cases of ovarian cancer with 331 of them found to be advanced. ${ }^{1}$ Seventy percent of ovarian epithelial cancer found to be advanced with number of survivor only $46 \%$ in 5 years. ${ }^{2}$

Therapeutic modalities for ovarian epithelial cancer are cytoreduction surgery and then followed by the administration of combination platinum and taxane as chemotherapy. However, the effectiveness of chemotherapy is only 60 up to 80 percent with higher degree of recurrence. Standard chemotherapy regimens are alkylating agents, anti-metabolites, DNA binder and cutters and spindle destroyers that might reduce tumors development, but often fail to eradicate or prevent recurrence and repeated chemotherapy with this regimen makes chemoresistance cancer cells. Recurrence in ovarian epithelial cancer remains a major problem in the treatment of ovarian epithelial cancer. The problem of recurrence of ovarian epithelial cancer is a resistance to standard chemotherapy treatment. Survival of patients with cases of resistance to chemotherapy averaged 6 months and even only $27 \%$ of cases survived more than 12 months. $^{3}$

Therefore, a sophisticated strategy is needed in developing effective therapeutic modalities in treating ovarian epithelial cancer. One of the strategies to improve the effectiveness of ovarian epithelial cancer therapy is conducting a co-chemotherapy effect of phytopharmaca. In the development of anticancer drugs in vivo requires experimental animal models for epithelial ovarian cancer. The use of animal models in the testing of epithelial ovarian cancer therapy is still needed considering that epithelial ovarian cancer treatment is still not optimal. Validation of experimental animal models that have histological characteristics of ovarian cancer is needed in humans, therefore animal models can be used in the development and testing of ovarian cancer drugs.

A number of models of ovarian cancer have been developed using various techniques including induction of carcinogens, steroid hormone stimulation and genetic engineering. Various chemical compounds can be used to induce tumor development in experimental animals, one of them is 7,1 dimethylbenz[a] anthrazene (DMBA). DMBA is a carcinogen with the empirical formula $\mathrm{C}_{20} \mathrm{H}_{16}$ known as a toxic compound for the body. DMBA is a group of polycyclic aromatic hydrocarbons (Polycylic Aromatic Hydrocarbon/PAHs) which can be found in motor vehicle fumes, petroleum residues, cigarette smoke and soot. DMBA is fat soluble so it can accumulate in adipose tissue. ${ }^{4}$

This is an open access article distributed under the terms of the Creative Commons Attribution-NonCommercial-ShareAlike 4.0 License, which allows others to remix, tweak, and build upon the work non-commercially, as long as the author is credited and the new creations are licensed under the identical terms. 
One of the way to make animal models of ovarian cancer is using carcinogens DMBA, which can induce cancer by forming DNA addcuts, inducing the initiation, promotion and progression of tumors. The incidence of ovarian cancer in experimental animals caused by DMBA varies between $10 \%$ to $45 \% .^{5}$ Therefore such possibility can be influenced by experimental animal sources and strains, dosage forms and the amount of DMBA given and delivery routes of DMBA. ${ }^{6}$ The route for DMBA delivery is important which correlates with tumor incidence. DMBA implantation in the ovary will give a different percentage of incidence by giving the DMBA with oral and intravenous injection. ${ }^{7}$ The ovarian cancer model was developed by implanting surgical threads coated with DMBA carcinogens in the rat ovary is proposed in this study. DMBA will damage the ovarian stroma which can cause various types of ovarian cancer such as epithelial tumors, sarcomas and granular cell tumors. Induction of DMBA with this method gained an incidence of ovarian cancer reaching $75 \%$ at 32 weeks with a dominant picture of adenocarcinoma (93.75\%). This method can be used to make animal models of ovarian cancer, that can resemble carcinogenesis in humans therefore can be used for studies and therapy development to ovarian cancer. In this study, female rat ovaries were induced using DMBA. DMBA coated on silk threads, then implanted in female ovaries to obtain animal models of epithelial type ovarian cancer. $^{6}$

Early detection of ovarian cancer provides a better life and is useful in controlling the progression of the disease. ${ }^{8}$ Detection of ovarian cancer is also useful in developing animal models of ovarian cancer therefore can be used in ovarian cancer drug testing. Various modalities of radiological examination are used to detect ovarian cancer, including Ultrasonography (USG). USG is a simple, inexpensive and non-invasive examination for evaluation of abnormal gynecologic findings including ovaries. Using the USG, the ovaries can be visualized more than $95 \%$ in pre-menopausal women and more than $85 \%$ in post-menopausal women. The use of transabdominal ultrasound (TAS) for the diagnosis of malignancy of tumor mass has a specificity of $42-95 \%$ and a sensitivity of $60-93 \%$, the disadvantage is not able to distinguish the type of ovarian tumor. ${ }^{9}$ Ultrasonography can determine the size, amount and relative location of each ovarian follicle. A wave-developmental pattern shows synchronous growth of a group of follicles in response to a flow in circulating concentrations of follicle-stimulating hormone, that usually followed by continued growth of dominant follicle and rapid die-off of the subordinates. ${ }^{10}$ Another study said the use of ultrasonography showed the wave-like pattern extends to antral follicles as small as $1 \mathrm{~mm}$ and the largest group at wave emergence is destined to become the dominant follicles. Hence, the study of ovarian follicular development in rodents has been based on one-time histological examination of excised tissues; i.e., longitudinal study of day-to-day ovarian changes has not been possible in rats. The objective is to establish an ultrasonography approach to study follicular and luteal dynamics in rats. ${ }^{11}$ This research aims to obtain animal models of epithelial ovarian cancer with implantation DMBA and use of ultrasonography to detect ovarian cancer growth.

\section{MATERIALS AND METHODS}

\section{Materials}

7,12-dimethylbenz(a)anthracene (DMBA) (Sigma Chemical Co., St. Louis, MO), silk suture, female Wistar rats (obtained from National Institute of Research and Development, Ministry of Health of Republic Indonesia), ketamine hydrochloride Injection,USP (Hospira,Inc.,USA), xylazine (Interchemie,Holland), portable ultrasonography console Chison Q8' (PT Mega Utama Medica, Indonesia).

\section{Preparation of DMBA-Coated Silk Suture 3-0}

DMBA is heated at $124^{\circ} \mathrm{C}$, which is the boiling point of the DMBA. Approximately $1,5 \mathrm{~cm} 3-0 \mathrm{~cm}$ silk thread is placed on the melted DMBA. Silk suture will be coated in DMBA approximately 2-3 mg.

\section{Procedure of Ovarian Cancer Induction}

Twenty eight female Wistar rats (obtained from National Institute of Reseach and Development, Ministry of Health of Republic Indonesia) on 5 weeks old. They were quarantined and acclimatized for one week, kept in the animal chamber which controlled the room temperature at a temperature of $25 \pm 2^{\circ} \mathrm{C}$, humidity is $65 \pm 10 \%$, air ventilation $11-13$ times per $\mathrm{hr}$ and illumination $12 \mathrm{hrs}$ per day $(07.00$ - 19.00). The animals are fed with standard pellets and ad libitium drinking. Surgery begins by giving anesthesia with intraperitonial using ketamine hydrochloride $(75 \mathrm{mg} / \mathrm{kg}$ body weight) and xylazine ( $8.8 \mathrm{mg} / \mathrm{kg}$ body weight). Surgery is performed on the retroperitoneal part and the ovary is removed from fat tissue. Silk suture 3-0 which is coated with DMBA is implanted in ovarian tissue and the wound is closed again. After the surgical process, the rats are kept fed according to the conditions above. Weight is measured regularly. Tumor size and volume were observed by palpation every week after surgery on the left body of the rat's abdomen. It takes at least 20 weeks for tumor formation from the implantation process. This research was carried out after obtaining approval from the Health Research Ethics Committee of the Faculty of Medicine Universitas Indonesia with number: 0531/UN2.F/ETIK/2018. All actions were taken by minimizing pain and suffering in experimental animals.

\section{Procedure of Examination with Ultrasonography}

Wistar strain female rats that have been induced with ovarian cancer, at the $20^{\text {th }}$ week ultrasound examination was performed to observe the development and growth of ovarian tissue. Rats were anesthetized intravenously using ketamine $(75 \mathrm{mg} / \mathrm{kg}$ body weight $)$ and xylazin $(8.8 \mathrm{mg} / \mathrm{kg}$ body weight). Rat's hairs on the peritoneal part are shaved and cleaned. Ultrasonography gel was applied on the peritoneal surface. Ultrasonography imaging of rat ovarian was perfomed using portable ultrasonography console Chison Q8 ${ }^{\circ}$ (PT Mega Utama Medica, Indonesia). The sonogram was caught from the transversal and longitudinal point of view using transducer multi linear frequency of 7,5-15 MHz. The sonogram was saved in the form of BMP for futher analysis using ImageJ software (NIH, USA).

\section{Preparation and Tissue Analysis for Histopathology}

To minimize pain, suffering or distress during experimentation, all of the animal were anesthetized with ketamine $(75 \mathrm{mg} / \mathrm{kg})$ and xylazine $(8.8 \mathrm{mg} / \mathrm{kg})$ prior to decapitation therefore they were rendered unconscius. At 180 days of age, euthanasia was performed in accordance with The Ethics Committee of the Faculty of Medicine, Universitas Indonesia, with regards of the protection of human rights and welfare in medical research, Ethics number: 0531/UN2.F1/ETIK/2018. Rats were dissected and part of the left and right ovaries were taken, morphology was observed and measurements were taken of the left and right ovaries. The fixation ovarian organs with $10 \%$ formalin buffer for $24-48 \mathrm{hrs}$. Tissue preparations that have been processed are then stained with Hematoxylin-Eosin (HE) staining. ${ }^{12}$ Histopathological analysis was carried out by anatomical pathologists. Histological characteristics of ovarian cancer cells can be seen in Table 1 .

\section{Data Analysis}

Data is presented in the form of mean \pm standard deviation (SD). Comparison of the variable distribution between the two groups was carried out using the t-test with a significance limit ( $\alpha$ ) 0.05 . The value of $P<0,05$ 
Table 1: Histologic subtyping of DMBA-induced ovarian carcinomas in rats. ${ }^{6}$

\begin{tabular}{|c|c|c|}
\hline Tumor subtypes & & Histologic features \\
\hline \multirow[t]{4}{*}{ Adenocarcinoma } & Serous carcinoma & $\begin{array}{c}\text { An adenocarcinoma } \\
\text { characterized by a pattern of } \\
\text { papillae with cellular budding }\end{array}$ \\
\hline & $\begin{array}{l}\text { Endometroid } \\
\text { carcinoma }\end{array}$ & $\begin{array}{l}\text { An adenocarcinoma } \\
\text { composed of simple or } \\
\text { pseudostratified epithelial } \\
\text { cells, or occasionally with } \\
\text { squamous differentiation }\end{array}$ \\
\hline & $\begin{array}{l}\text { clear cell } \\
\text { carcinoma }\end{array}$ & $\begin{array}{l}\text { An adenocarcinoma mainly } \\
\text { composed of hobnail cells }\end{array}$ \\
\hline & $\begin{array}{l}\text { mucinous } \\
\text { carcinoma }\end{array}$ & $\begin{array}{l}\text { An adenocarcinoma } \\
\text { composed of endocervical-like } \\
\text { and intestinal type cells }\end{array}$ \\
\hline Granulosa cell tumor & & $\begin{array}{l}\text { A neoplasm composed of } \\
\text { granulosa cells }\end{array}$ \\
\hline Squamous carcinoma & & $\begin{array}{l}\text { A carcinoma composed of } \\
\text { squamous epithelial cells }\end{array}$ \\
\hline Sarcoma & & $\begin{array}{l}\text { A neoplasm composed of } \\
\text { malignant nonepithelial cells }\end{array}$ \\
\hline Malignant teratoma & & $\begin{array}{c}\text { Teratoma with any malignant } \\
\text { contents }\end{array}$ \\
\hline $\begin{array}{l}\text { Undifferentiated } \\
\text { carcinoma }\end{array}$ & & $\begin{array}{c}\text { A carcinoma with no } \\
\text { Specifically differentiated cells }\end{array}$ \\
\hline Benign ovarian tumor & & $\begin{array}{c}\text { All tumors without malignant } \\
\text { characters }\end{array}$ \\
\hline
\end{tabular}

Table 2: Sonograms of left and right ovarian rats.

\begin{tabular}{ccc}
\hline Sonogram of rat ovarian & Left ovarian & Right ovarian \\
\hline Longitudinal diameter $(\mathrm{cm})$ & $1.705 \pm 0.222^{\mathrm{a}}$ & $0.527 \pm 0.086^{\mathrm{a}}$ \\
Transversal diameter $(\mathrm{cm})$ & $0.910 \pm 0.085^{\mathrm{a}}$ & $0.388 \pm 0.076^{\mathrm{a}}$ \\
Size $\left(\mathrm{cm}^{2}\right)$ & $1.567 \pm 0.264^{\mathrm{a}}$ & $0.204 \pm 0.045^{\mathrm{a}}$ \\
Volume $\left(\mathrm{cm}^{3}\right)$ & $0.755 \pm 0.19^{\mathrm{a}}$ & $0.043 \pm 0.016^{\mathrm{a}}$ \\
\hline
\end{tabular}

Data are presented in the form of average and standard deviation $(x \pm S D)$. The different superscript shows a significant difference $(P<0,05)$.

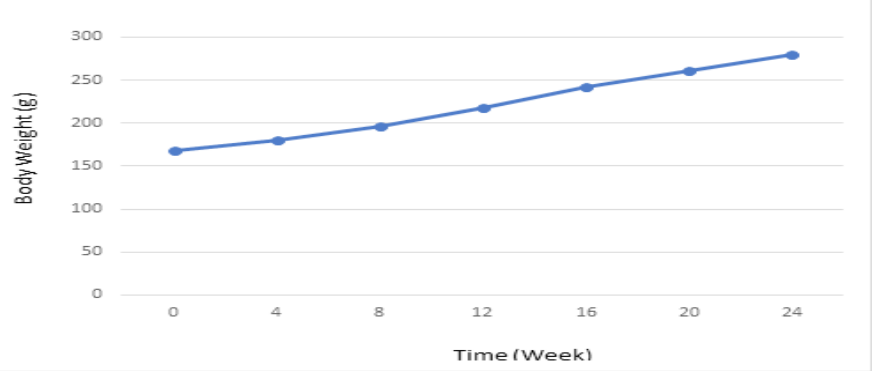

Figure 1: Graph of rat weight gain during experiment. showed a significant difference between the group. All statistical analyzes were carried out with SPSS v.16.0 SPSS Inc., USA.

\section{RESULTS}

\section{DMBA-Coated Silk Suture 3-0 and Ovarian Cancer Induction in Rats}

In this study, female rats were induced using DMBA implanted in the female ovary of rats to obtain animal models of epithelial type ovarian cancer. The weight of the DMBA attached to the silk thread is 3-0 approximately 2-3 mg. After surgery and implantation of DMBA in the ovaries of rats, they were kept in controlled room and fed with standard pellets and ad libitium of drinking. Body weight is weighed regularly and palpation is examined on the abdomen to see nodule growth. A graph of observation of body weight of rats can be seen at Figure 1.

\section{Macroscopic Overview of Nodules and Incidence of Nodule Formation}

Rats are examined periodically to see the development of nodules that form on the abdomen of rats. At week 24, nodules measuring approximately $1.5 \mathrm{~cm}$ can be clearly observed. The following are nodules that appear on the left side of the rat's abdomen. Incidence of nodule formation from the date of suture implantation to the time of palpation or discovery at termination of the experiment can be seen at Figure 2 .

\section{Ultrasonography Imaging on Ovarian Rats}

At $20^{\text {th }}$ weeks an ultrasound examination was carried out on rats, to see the development of size and volume of the ovary. Ultrasonographic imaging of ovarian rats can be seen at Figure 3 and sonograms of ovarian rats can be seen at Figure 4. Sonograms of left ovarian rats and right ovarian rats can be seen in Table 2. Ultrasonography showed that the mean left ovary size of rats induced by DMBA was $1,567 \pm 0,264 \mathrm{~cm}^{2}$ and the right ovarian size of non-DMBA induced rats was 0,204 $\pm 0,045$ $\mathrm{cm}^{2}$ (Figure 5). Based on the results of the statistical analysis of normality test (Kolmogorov-smirnov test) and homogeneity test (Levene test) with a significance value of homogeneity of 0.200 ( $p>0.05$ ). It can be concluded that the ovary size of rats is normally distributed and varies homogeneously. Furthermore the analysis continued with independent sample T-test and obtained a significance value of rat ovary size of 0.000 $(p<0.05)$. These results indicate that there are significant differences between the size of the left ovary and right ovary in rats.

Ultrasonography showed that the mean left ovary volume of rats induced by DMBA was $0,755 \pm 0,19 \mathrm{~cm}^{3}$ and the right ovarian volume of nonDMBA induced rats was $0,043 \pm 0,016 \mathrm{~cm}^{3}$ (Figure 6). Based on the results of the statistical analysis of normality test (Kolmogorov-smirnov

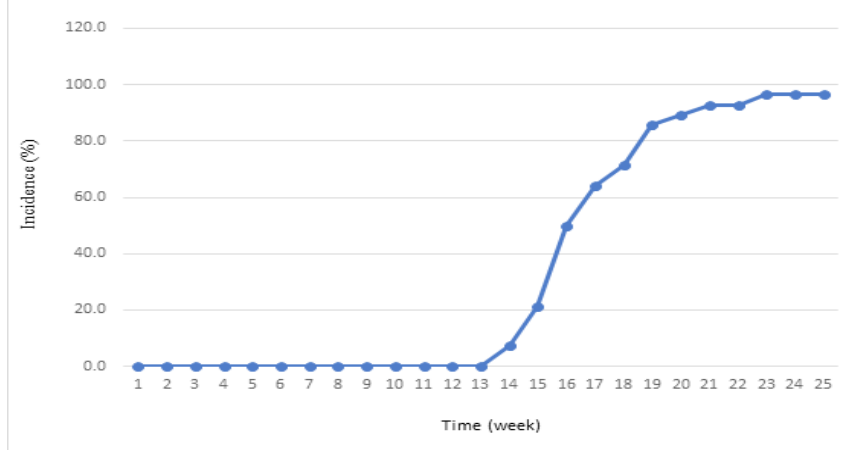

Figure 2: Incidence of nodule formation from the date of suture implantation to the time of palpation or discovery at termination of the experiment. 


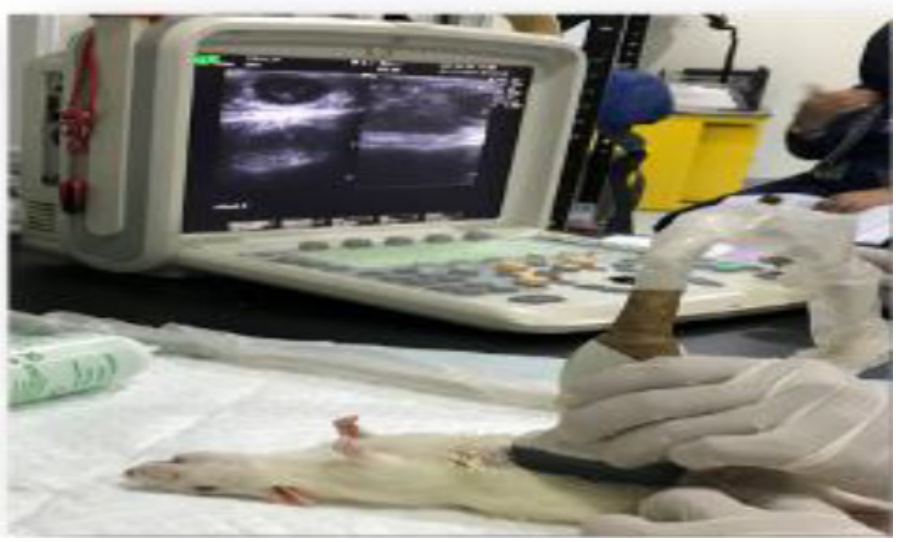

Figure 3: Ultrasonographic imaging of ovarian rats.

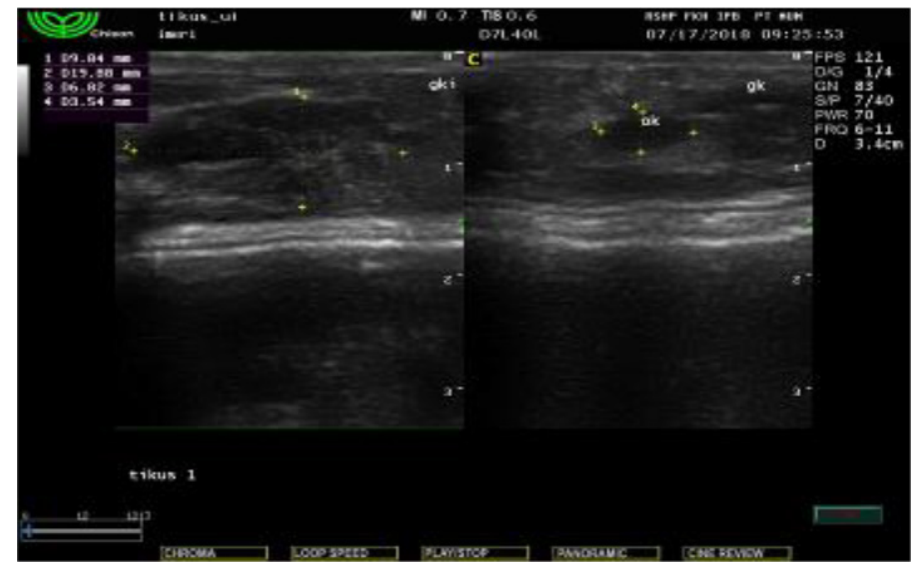

Figure 4: Sonograms of ovarian rats.

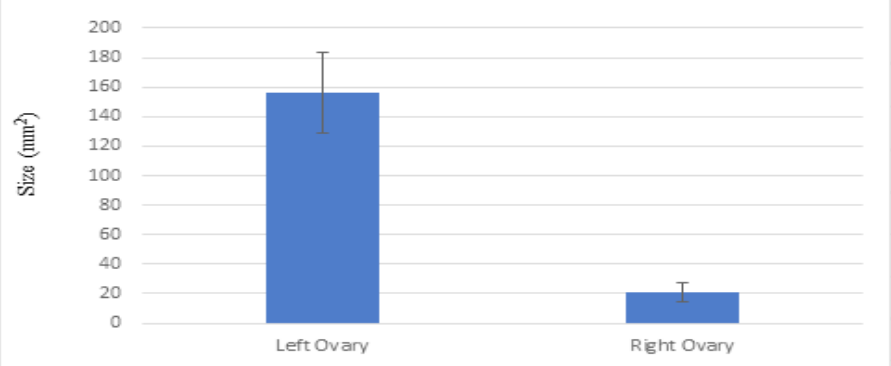

Figure 5: The average and standard deviation $(x \pm S D)$ ovarian size at $20^{\text {th }}$ week.

test) and homogeneity test (Levene test) with a significance value of homogeneity of 0.200 ( $p>0.05)$ it can be concluded that the ovary size of rats is normally distributed and varies homogeneously. The analysis is continued with independent sample T-test and obtained a significance value of rat ovary size of $0.000(p<0.05)$. These results indicate that there are significant differences between the size of the left ovary and right ovary in rats.

\section{Macroscopic Overview of Epithelial type Ovarium Cancer Result of DMBA}

At week $24^{\text {th }}$, the histopathology was examined in several rats. Histological examination was performed with HE staining. Rats were dissected,

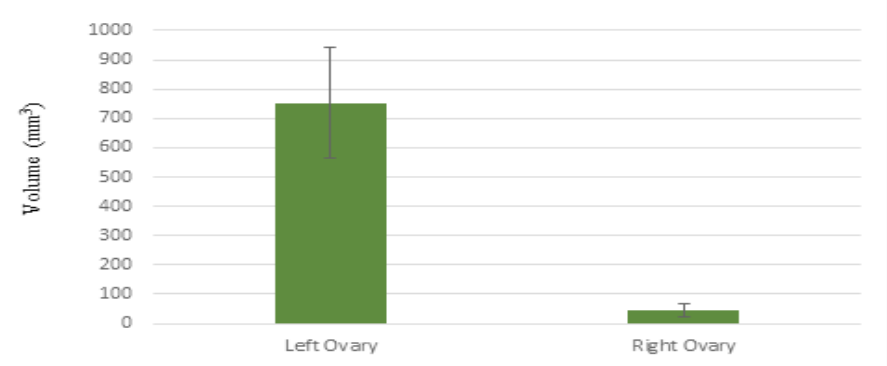

Figure 6: The average and standard deviation $(x \pm S D)$ ovarian volume at $20^{\text {th }}$ week.
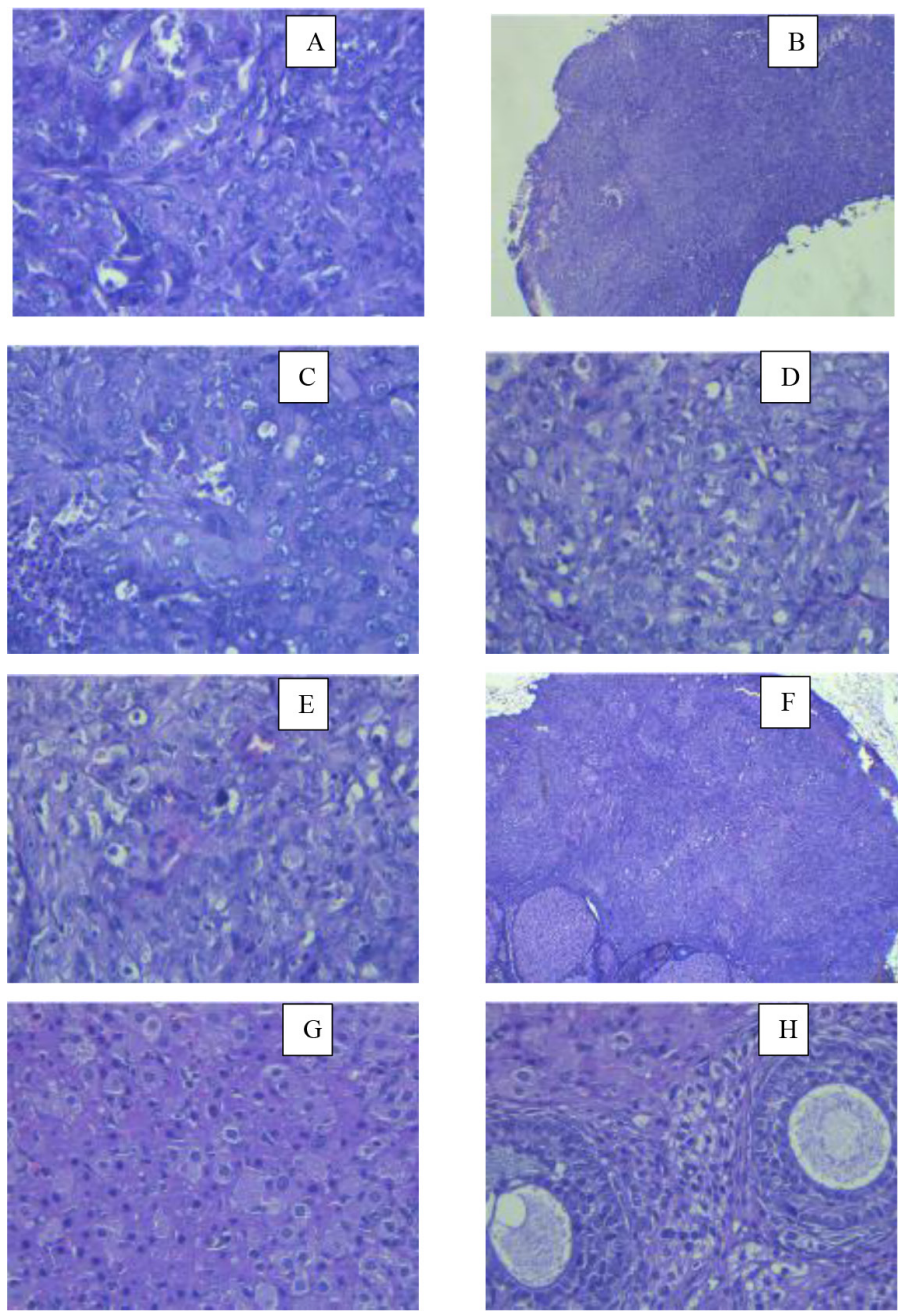

Figure 7: Left ovary histology (A) Serous carcinoma characterized by papillae formation with celular budding (arrow) (40x). (B)Serous carcinoma with a pattern of papillae (4x). (C)Clear cell carcinoma composed of numerous vacuolated cells (40x). (D)Clear cell carcinoma composed of numerous vacuolated cells (40x). (E)Sarcoma (40x). (F)Squamous carcinoma composed a squamous ephitelialcells (asterisk); (G) and (H) sel-sel normal cells at right ovary histology (40x); HE stain (10x and 40x). 
then the right and left ovaries, was taken out and stored in $10 \%$ formalin buffer.

\section{Histopathological Overview of Malignancy Result of DMBA}

Histopathological examination aims to assess tissue in the left ovary and right ovary in rats. Histopathological examination was performed using Hematoxylin-Eosin staining. The tissue is examined under a $10 \mathrm{x}$ and $40 \mathrm{x}$ magnification microscope. Examination results on the left ovary in the $24^{\text {th }}$ week appear histologic subtyping of DMBA-induced ovarian carcinomas in rat that is serous carcinoma characterized by papillae formation with celular budding (arrow), serous carcinoma with a pattern of papillae $(4 \mathrm{x})$, clear cell carcinoma composed of numerous vacuolated cells, clear cell carcinoma composed of numerous vacuolated cells, sarcoma and squamous carcinoma composed a squamous ephitelial cells (asterisk) (Figure 7 (A)-(F)). On histopathological examination at the $24^{\text {th }}$ week, DMBA induced rats showed that they had undergone transformation of ovarian cells into ovarian carcinoma. However in the right ovary that does not get DMBA induction, no transformation occurs in ovarian cells (Figure $7(\mathrm{G})$ and $(\mathrm{H})$ ).

\section{DISCUSSION}

In this research animal models of Wistar laboratory rats were used. The selection of rats as experimental animal models has the advantage of lower costs, easier handling and supervision and simpler ethical problems compared to other experimental animals with higher taxonomic levels. ${ }^{13-14}$ The same physiological patterns and organ responses to hormones between humans and rats, make rats can be a good model for analyzing carcinogenesis patterns in humans. ${ }^{14-15}$

This study succeeded in inducing the formation of ovarian cancer in a group of rats given DMBA induction for 20 weeks. Crist et al. in 2005 showed that direct DMBA implantation in rats ovaries can induce ovarian carcinoma. ${ }^{5}$ The use of chemical carcinogens aims to trigger ovarian cancer by using DMBA coated thread implants on the ovary. The selection of DMBA is a carcinogen commonly used in cancer induction studies and is known to have the ability to interact directly with DNA and cause DNA mutations. ${ }^{13}$

DMBA is an environmental carcinogen which has a potent ovotoxic effect on ovaries, causing complete follicular depletion resulting in premature ovarian failure. Overall, effects of DMBA on ovarian folliculogenesis are well known, but the exact molecular mechanisms behind its ovotoxicity is little known. They characterized the mechanisms behind DMBA-induced ovotoxicity in immature follicles. ${ }^{16}$ DMBA has also disrupt folliculogenesis, causing depletion of all follicle populations leading to premature ovarian failure (POF). ${ }^{17}$

In the ovary, DMBA is converted into a 3,4-diol 1,2- epoxide by members of the cytochrome P450 family of oxidases and the microsomal epoxide hydrolase enzyme. ${ }^{18}$ This bioactive metabolite binds to both dAdo and dGuo residues in DNA, forming DMBA-DNA adducts which result in follicular atresia. ${ }^{19}$ Recent evidence suggests that DMBA does not cause POF through increased follicular activation, consequently resulting in accelerated atresia in both primordial and primary follicles in rodents, ${ }^{20}$ but instead causes direct follicle atresia.

Another significantly upregulated pathway was methionine metabolism. Methionine metabolism is an important aspect of cellular physiology, involved in preventing oxidative stress and cell cycle progression. ${ }^{21}$ As DMBA metabolism causes elevated levels of reactive oxygen species in the ovary, its upregulation in DMBA-treated ovaries may be a mechanism utilized by the ovary to prevent DMBA-induced oxidative stress. ${ }^{22}$ In further support of a complex mechanism of DMBA- induced ovotoxicity, qPCR analysis confirmed the upregulation genes involved in a variety of cellular processes. One of these genes was Ddx 5 , a member of the DEAD-box RNA helicase family. ${ }^{23}$ DMBA induces follicular atresia by upregulation of Ddx 5 and Foxn3. Both Ddx 5 and Foxn 3 have been shown to induce and prevent tumorigenesis, respectively. Ddx5 acts a coactivator of estrogen receptor alpha, up regulating its expression and promoting growth/cell survival in cancer cell lines. ${ }^{24}$ Despite apparent selective gene expression modulation, DMBA-induced ovotoxicity may involve a variety of other mechanisms apart from follicular atresia. DMBA-induced preantral ovotoxicity involving selective immature follicle destruction and primordial follicle activation involving downstream members of the PI3K/Akt and mTOR signaling pathways, increased Akt1 phosphorylation, mTOR activation and decreased FOXO3a expression. ${ }^{16}$ DNA adducts will also be eliminated by nucleotide excision repair however if there is no improvement it will cause permanent mutations. Point mutations can also be formed, namely changes in adenine bases to thymine and adenine to guanine. ${ }^{25}$ If these mutations occur in tumor suppressor genes or oncogenes, they can trigger cellular transformation and tumor development. ${ }^{26}$ DMBA metabolism causes DNA damage that affects regulatory genes growth so that uncontrolled growth will occur. Excessive growth occurs in all cells including endothelial cells and affects the increased production of VEGF and angiogenesis., ${ }^{47}$

According to the results of this experimental test, the use of DMBA implantation techniques coated on the thread can induce ovarian cancer formation. Histopathological features examined with $\mathrm{HE}$ staining techniques showed that the appearance of ovarian tissue found was consistent with the description of ovarian cancer in humans. The use of ultrasonography imaging to observe changes in ovarian size also shows good result. There was a difference in the size of the left ovary that received DMBA and right ovarian induction which was not induced by DMBA. This technique requires further development. In ovarian cancer, there is a development of tumor growth, especially malignant tumors that will result in neovascularization, so that the development of malignant tumor tissue is very fast and uncontrolled. The walls of the blood vessels have less smooth muscle than normal blood vessels, so their resistance is smaller, especially in the arterioles. This decrease in resistance can be known using Color Doppler Imaging (CDI) with a sensitivity of $96.4 \%$ and specificity of $99.8 \%$. However, the CDI examination is quite expensive and requires operator experience that limits the use of this tool. ${ }^{9}$

\section{CONCLUSION}

DMBA implanted in the ovaries of female rats can be an experimental animal models of epithelial type ovarian cancer and the ultrasonography imaging can determine the size and volume of tumors formed in the ovary.

\section{ACKNOWLEDGEMENT}

We gratefully acknowledge the financial support of the Ministry of Research Technology and Higher Education, National Ministry of Republic Indonesia for research grant of Penelitian Unggulan Perguruan Tinggi (PUPT) 2018.

\section{CONFLICT OF INTEREST}

The authors declare no conflict of interest. 


\section{ABBREVIATIONS}

DMBA: 7,12-Dimethylbenz[a]anthracene; PAHs: Polycylic Aromatic Hydrocarbon; USG: Ultrasonography; TAS: Transabdominal Ultrasound; POF: Premature Ovarian Failure; PI3K: Phosphoinositide 3-kinase; VEGF: Vascular Endothelial Growth Factor; CDI: Color Doppler Imaging.

\section{REFERENCES}

1. Ferlay J, Soerjomataram I, Dikshit R, et al. Cancer incidence and mortality worldwide: sources, methods and major patterns in GLOBOCAN 2012. Int J Cancer. 2015;136(5):E359-86.

2. Terlikowska KM, Witkowska AM, Zujko ME, Dobrzycka B, Terlikowski SJ. Potential application of curcumin and its analogues in the treatment strategy of patients with primary epithelial ovarian cancer. Int J Mol Sci. 2014;15(12):21703-22

3. Yallapu MM, Maher DM, Sundram V, Bell MC, Jaggi M, Chauhan SC. Curcumin induces chemo/radio-sensitization in ovarian cancer cells and curcumin nanoparticles inhibit ovarian cancer cell growth. J Ovarian Res. 2010;3(1):11.

4. Rengarajan T, Rajendran $P_{1}$ Nandakumar N, Lokeshkumar B, Rajendran $P_{1}$ Nishigaki I. Exposure to polycyclic aromatic hydrocarbons with special focus on cancer. Asian Pac J Trop Biomed. 2015;5(3):182-9.

5. Crist KA, Zhang Z, You M, et al. Characterization of rat ovarian adenocarcinomas developed in response to direct instillation of 7,12-dimethylbenz[a]anthracene (DMBA) coated suture. Carcinogenesis. 2005;26(5):951-7.

6. Huang Y, Jiang W, Wang Y, Zheng Y, Cong Q, Xu C. Enhanced efficacy and specificity of epithelial ovarian carcinogenesis by embedding a DMBA-coated cloth strip in the ovary of rat. J Ovarian Res. 2012;5(1):21.

7. Kuwahara I. Experimental induction of ovarian tumors in mice treated with single administration of 7, 12-dimethylbenz [a] anthracene and its histopathological observation. GANN Japanese J Cancer Res. 1967;58(3):253-66_255.

8. Rauh-Hain JA, Krivak TC, Carmen DMG, Olawaiye AB. Ovarian cancer screening and early detection in the general population. Rev Obstet Gynecol. 2011;4(1):15.

9. Singh $U$, Kohli $N$, Nisha E. Evaluation of new scoring system to differentiate between benign and malignant adnexal mass. Obstet Gynecol India. 2006;56:162-5.

10. Singh J, Adams GP, Pierson RA. Promise of new imaging technologies for assessing ovarian function. Anim Reprod Sci. 2003;78(3-4):371-99.

11. Jaiswal RS, Singh J, Adams GP. High-resolution ultrasound biomicroscopy for monitoring ovarian structures in mice. Reproductive Biology and Endocrinology $2009 ; 7(1): 69$.

12. Fischer $A H$, Jacobson KA, Rose J, Zeller R. Hematoxylin and eosin staining of tissue and cell sections. Cold Spring Harb Protoc. 2008;2008(5):pdb-rot4986.

13. Oliveira KDD, Avanzo GU, Tedardi MV, et al. Chemical carcinogenesis by DMBA (7, 12-dimethylbenzanthracene) in female BALB/c mice: new facts. Braz J Vet
Res Anim Sci. 2015;125-33.

14. Jafari S, Morteza S, Hunger R. IHC Optical Density Score: A New Practical Method for Quantitative Immunohistochemistry Image Analysis. Appl Immunohistochem Mol Morphol. 2017;25(1):e12-e13.

15. Anisimov VN, Ukraintseva SV, Yashin Al. Cancer in rodents: does it tell us about cancer in humans?. Nat Rev Cancer. 2004;5(10):807.

16. Sobinoff AP, Mahony M, Nixon B, Roman SD, McLaughlin EA. Understanding the Villain: DMBA-induced preantral ovotoxicity involves selective follicular destruction and primordial follicle activation through PI3K/Akt and mTOR signaling. Toxicol Sci. 2011;123(2):563-75.

17. Mattison D, Schulman J. How xenobiotic chemicals can destroy oocytes. Contemp Obstet Gynecol. 1980;15:157.

18. Igawa Y, Keating AF, Rajapaksa KS, Sipes IG, Hoyer PB. Evaluation of ovotoxicity induced by 7, 12-dimethylbenz [a] anthracene and its 3, 4-diol metabolite utilizing a rat in vitro ovarian culture system. Toxicol Appl Pharmacol. 2009;234(3):361-9.

19. Vericat J, Cheng S, Dipple A. Absolute stereochemistry of the major 12-dimethylbenz (a) anthracene-DNA adducts formed in mouse cells. Carcinogenesis. 1989;10(3):567-70

20. Keating AF, Fernandez SM, Mark-Kappeler CJ, Sen N, Sipes IG, Hoyer PB. Inhibition of PIK3 signaling pathway members by the ovotoxicant 4-vinylcyclohexene diepoxide in rats. Biol Reprod. 2011;84(4):743-51.

21. Moskovitz J, Berlett BS, Poston JM, Stadtman ER. The yeast peptide-methionine sulfoxide reductase functions as an antioxidant in vivo. Proceedings of the National Academy of Sciences. 1997:94(18):9585-9.

22. Tsai-Turton M, Nakamura BN, Luderer U. Induction of apoptosis by 9, 10-dimethyl-1, 2-benzanthracene in cultured preovulatory rat follicles is preceded by a rise in reactive oxygen species and is prevented by glutathione. Biol Reprod. 2007;77(3):442-51.

23. Nicol SM, Fuller-Pace FV. Analysis of the RNA helicase p68 (Ddx5) as a transcriptional regulator. In: Helicases. Springer. 2009;265-79.

24. Fuller-Pace FV, Moore HC. RNA helicases p68 and p72: multifunctional proteins with important implications for cancer development. Future Oncol. $2011 ; 7(2): 239-51$.

25. Chakravarti D, Pelling JC, Cavalieri EL, Rogan EG. Relating aromatic hydrocarboninduced DNA adducts and $\mathrm{cH}$-ras mutations in mouse skin papillomas: the role of apurinic sites. Proceedings of the National Academy of Sciences. 1995;92(22):10422-6.

26. Kropachev K, Kolbanovskiy M, Liu Z, et al. Adenine-DNA adducts derived from the highly tumorigenic dibenzo [a, I] pyrene are resistant to nucleotide excision repair while guanine adducts are not. Chem Res Toxicol. 2013;26(5):783 93.

27. Akrom A, Fatimah F. Ekstrak Heksan Biji Jintan Hitam (Nigella sativa L) Meningkatkan Aktivitas Fagositosis Makrofag Tikus Betina Galur SD (Sprague Dawley) Yang Diinduksi DMBA (7,12 dimetilbenz $(\alpha)$ antrasen) secara In vitro. Pharmaciana. 2015;5(1)

Article History: Submission Date : 15-11-2018; Revised Date : 30-11-2018; Acceptance Date : 05-12-2018.

Cite this article: Sandhiutami NMD, Arozal W, Louisa M, Rahmat D, Wuyung PE, Ulum MF. Induction of Epithelial Ovarian Cancer by implantation of 7,12-dimethylbenz(a)athracene (DMBA) Coated Silk in Rat for Study Anticancer in vivo. J Young Pharm. 2019;11(1):56-61. 